\title{
The Summa Halensis on Theology and the Sciences: The Influence of Aristotle and Avicenna
}

\begin{abstract}
This chapter investigates the conception of theology as a science in the Summa Halensis, and shows how the author of book I utilizes the theories of Aristotle and Avicenna. The Summist introduces his own innovative system of the sciences, into which theology is integrated. I argue that in justifying the claim that theology is a science and in explaining how both metaphysics and theology are wisdom, the author takes over Aristotle's theory of what constitutes a science and his definition of wisdom and uses Avicenna's terminology for the first cause. In his solution to the problem of the subject-matter of theology, he adopts Avicenna's influential distinction between the proper subject-matter of a science and that which it seeks. Instead of Avicenna's own expressions, however, he uses the vocabulary of Augustine and Peter Lombard. The chapter thus shows how the author reacts to the newly available sources translated from the Arabic and incorporates them into his own framework. Under their influence, the Summa suggests a solution to the novel problem of theology as a science by creating a theory of theology which combines the requirements of 'sacred doctrine' with a philosophical, rational concept of science.
\end{abstract}

Over the course of the 12th century and into the early 13th century, the theory of science in the Latin Christian world changed considerably under the influence of not only new and better translations of Aristotle - especially the Posterior Analytics but also philosophical sources translated from the Arabic such as the works of Avicenna. ${ }^{1}$ Consequently, the methodological requirements of a science and the relations between the different sciences, their order and their interdependence, were widely debated. In this climate, the question of the scientific status of Christian theology came into focus. As far as we know, Roland of Cremona was the first to explicitly discuss theology as a science. ${ }^{2}$ But if theology is a science, is it a science according to the criteria put forth by Aristotle in the Posterior Analytics? Or is it wisdom in the Augustinian sense? What is its methodology and its inner structure, its relation to

\footnotetext{
1 Charles Burnett, 'Arabic into Latin,' in The Cambridge Companion to Arabic Philosophy, eds. Peter Adamson and Richard C. Taylor (Cambridge: Cambridge University Press, 2004), pp. 370 - 404, esp. pp. 373-74; Charles Burnett, 'The Coherence of the Arabic-Latin Translation Program in Toledo in the Twelfth Century,' Science in Context 14 (2001), pp. 249-88.

2 Charles R. Hess, 'Roland of Cremona's Place in the Current of Thought,' Angelicum 45 (1968), pp. 429-77, esp. pp. 453-55.
} 
faith and the human intellect? And what is theology about? These questions were widely debated in the 13 th century. ${ }^{3}$

The Summa Halensis is one of the earliest texts to answer these questions. In this article I will claim that it does so by taking over doctrines from Aristotle and Avicenna and incorporating them into its own original theory. Thus, the Summa can defend theology as a genuine science while also keeping it distinct from other sciences by devising a system of distinctions between different types of scientific endeavour. Finally, the Summist can solve the problem of what theology is about as a science by adopting Avicenna's theory of the subject-matter of metaphysics.

The Summa Halensis was composed shortly after the newly-translated sources had become available, but before an established way of dealing with these new authorities had been developed. It has recently been shown that the authors of the Summa Halensis indeed rely heavily in many areas of their philosophy on both Aristotle and Avicenna. ${ }^{4}$ As was common at the time, they seem to have read the two authors side by side, not always clearly distinguishing between them, and interpreting Aristotle through the lens of Avicenna. ${ }^{5}$ There are cases in which a theory which was actually established by Avicenna is ascribed to Aristotle, or in which an Aristotelian theory is cloaked in Augustinian language. ${ }^{6}$ The authors of the Summa Halensis refer to both Aristotle and Avicenna frequently, ${ }^{7}$ but they are not always straightforward in reporting their sources. So the influence of Aristotle and Avicenna is not immediately obvious in its full extent.

In the following, I will investigate how the author of the beginning of the first book of the Summa Halensis - probably John of La Rochelle ${ }^{8}$ - grappled with

3 Oleg V. Bychkov, 'The Nature of Theology in Duns Scotus and His Franciscan Predecessors,' Franciscan Studies 66 (2008), pp. 5-62, esp. pp. 13-15; Philotheus Boehner, 'The System of Metaphysics in Alexander of Hales,' Franciscan Studies 5:4 (1945), pp. 366-414, esp. pp. 369-70.

4 Amos Bertolacci, 'Reading Aristotle with Avicenna: On the Reception of the Philosophia Prima in the Summa Halensis,' in The Summa Halensis: Sources and Context, ed. Lydia Schumacher (Berlin: De Gruyter, 2020), pp. 135-54; Jan Aertsen, Medieval Philosophy as Transcendental Thought: From Philip the Chancellor (ca. 1225) to Francisco Súarez (Leiden; Boston: Brill, 2012), pp. 136-38, 142-47; Dag Nikolaus Hasse, Avicenna's De anima in the Latin West: The Formation of a Peripatetic Philosophy of the Soul 1160-1300 (London: The Warburg Institute, 2000), pp. 51-54; Lydia Schumacher, Early Franciscan Theology: Between Authority and Innovation (Cambridge: Cambridge University Press, 2019), pp. 60 - 64, 76-89, 108-16; Spencer E. Young, Scholarly Community at the Early University of Paris: Theologians, Education and Society, 1215-1248 (Cambridge: Cambridge University Press, 2014), pp. 97-98.

5 Amos Bertolacci, 'On the Latin Reception of Avicenna’s Metaphysics Before Albertus Magnus: An Attempt at Periodization,' in The Arabic, Hebrew and Latin Reception of Avicenna's Metaphysics, eds. Dag Nikolaus Hasse and Amos Bertolacci (Berlin: De Gruyter, 2012), pp. 197-223, esp. pp. 202-4. 6 Bertolacci, 'Reading Aristotle with Avicenna,' pp. 136, 146-52.

7 Victorin Doucet, Prolegomena in librum III necnon in libros I et II Summae fratris Alexandri, in Alexander of Hales, Doctoris irrefragabilis Alexandri de Hales Ordinis minorum Summa theologica (SH), 4 vols (Quaracchi: Collegium S. Bonaventurae, 1924-48), IV, Tome A, pp. xcv-cxx.

8 Doucet, Prolegomena, pp. ccclx-ccclxi. 
these diverse influences. In three steps I will present different aspects of the theory of theology as a science in the Summa Halensis, which represent three different ways of interacting with Aristotle and Avicenna as sources.

First, I will point out that in justifying its claim that theology is a science, the Summa conceptualizes theology in a very rationalistic manner. Even though the author quotes Augustine, he deliberately misrepresents his intention. The conception of science is much closer to that of Aristotle than that of Augustine, and theology is indeed a science in the full Aristotelian sense.

Secondly, I will investigate how the Summa Halensis situates theology among the other sciences from which the author carefully distinguishes it. The text introduces its own system of the sciences, into which theology is integrated. In this instance, when explaining that both theology and metaphysics fulfil the requirements of being wisdom albeit to different extents, the Summa Halensis is again strongly influenced by its pagan and Muslim sources. It takes over the criteria of what constitutes wisdom from Aristotle and adopts the terminology for the first cause from Avicenna, but it forms its own innovative system.

The third case is that of the subject-matter of the science of theology. In his solution to this problem, the Summa's author adopts Avicenna's influential distinction between the subject-matter of metaphysics and that which metaphysics seeks. He does not name his source, however, and instead uses the vocabulary of Augustine and Peter Lombard.

These three instances will not only clarify how the novel problem of theology as a science is dealt with in the Summa Halensis, but also show how the author reacts to the newly-available sources, in particular Aristotle's Metaphysics and Posterior Analytics and Avicenna's Metaphysics of The Healing, namely, by utilizing their characterizations of metaphysics to define theology and by creating a theory of theology that combines the requirements of 'sacred doctrine' with a philosophical, rational concept of science. While Aristotle is explicitly quoted in the passages analyzed here, Avicenna is not, but his influence is nevertheless clearly present. In his regard, the Summa stands as an example of the trend Amos Bertolacci has identified before 1240 of reading Aristotle under Avicenna's influence. ${ }^{9}$

\section{What Makes Theology a Science?}

In the very beginning of book I of the Summa Halensis, question 1, chapter 1, the author asks whether theology, which he interchangeably calls doctrina sacra, doctrina

9 Bertolacci, ‘On the Latin Reception of Avicenna’s Metaphysics,' pp. 202-4; Bertolacci, 'Reading Aristotle with Avicenna.' 
theologiae, theologia, or scientia Sacrae Scripturae,$^{10}$ is a science (Utrum doctrina theologiae sit scientia). His answer is unambiguous: theology is a science according to a set of criteria which, in line with Aristotle, conceptualize science as a rational, universal pursuit.

These criteria are first introduced in the form of arguments against the claim that theology could be a science. Hence, they all indicate a characteristic feature of sciences and then claim that theology does not exhibit it. These criteria are:

1. Sciences deal with intelligible things (scientia enim est intelligibilium). ${ }^{11}$

Quoting Augustine who states that certain things can only be believed but never be subject to intellection, ${ }^{12}$ the argument states that sciences are always about intelligible things. Things which cannot be grasped by our intellect cannot be the subject of a science. This criterion is applied to theology. Since, following Augustine, stories and history are such that they can only ever be believed but not known by the intellect, the argument concludes that, since large parts of theology are about stories and history, it cannot be a science.

2. Sciences are about universals (ars vero universalium). ${ }^{13}$

Strictly speaking, this criterion follows from the first, since according to Aristotle, particular things can be perceived by the senses or stored in memory and imagination, while abstract, universal knowledge is specific to the intellect. ${ }^{14}$ Therefore, sciences are about intelligibles and universals, and scientific knowledge is universal knowledge.

3. Sciences consist of things which can be known (ex scibilibus scientia). ${ }^{15}$

Faith refers to things which are credible; opinion refers to things which are conjectural, or about which an opinion can be formed. Likewise, the objects of scientific knowledge need to be of a certain nature. They are that of which we can have knowledge. Again, this criterion is implied in the first two, but the text makes a point of stating expressly that science does not deal with things about which we can have opinions, or which we can believe. The objects of science need to possess the property of being knowable.

10 Aaron Gies, 'Biblical Exegesis in the Summa Halensis,' in The Summa Halensis: Sources and Context, ed. Lydia Schumacher (Berlin: De Gruyter, 2020), pp. 11-31, esp. pp. 11-12; James R. Ginther, 'There is a Text in this Classroom: The Bible and Theology in the Medieval University,' in Essays in Medieval Philosophy and Theology in Memory of Walter H. Principe, CSB, eds. James R. Ginther and Carl N. Still (Burlington, VT: Ashgate, 2005), pp. 31-51.

11 SH I, Tr1, Q1, C1 (n. 1), arg. 1, p. 1.

12 Augustine, De diversis quaestionibus octoginta tribus I.48: De credibilibus, PL 40:31. See John Rist, 'Faith and Reason,' in The Cambridge Companion to Augustine, eds. Eleonore Stump and Norman Kretzmann (Cambridge: Cambridge University Press, 2001), pp. 26-39.

13 SH I, Tr1, Q1, C1 (n. 1), Ad quod arguet sic 2, p. 1. See Gies, 'Biblical Exegesis in the Summa Halensis,' pp. 15-17.

14 Aristotle, Metaphysics I.1, 981a6-17; Aristotle, Posterior Analytics I.31, 87b28-88a17.

15 SH I, Tr1, Q1, C1 (n. 1), Ad quod arguet sic 3, p. 2. 
Since theology is mostly concerned with individual stories, it is neither universal nor something which can be known. It is particular, deals with that which can be believed, and is, hence, not a science.

It is easy to see that these points rely heavily on Aristotle, that is, on his conception of intellectual knowledge and his theory of science. The Summa even provides a direct quotation from the very beginning of the Metaphysics and attributes it correctly:

Experience is [knowledge] of particulars, but science of universals; science develops when from many notions of experience one judgement develops about similar things. ${ }^{16}$

The passage as quoted is actually a composition of two different phrases from book A of Aristotle's Metaphysics in reverse order. ${ }^{17}$ Aristotle introduces here his distinction between different forms of cognition: sense perception, memory, experience, and science. This way of quoting shows clearly that the author was familiar with the text, and carefully chose the precise phrases that best expressed what the argument called for, namely, establishing a connection between abstracted universals and scientific knowledge.

The author of this question, however, does indeed defend the position that theology is a science and rejects all objections. But it is noteworthy that in doing so, the criteria for what constitutes a science are upheld. The individual answers to the arguments try to justify why theology actually fulfils the respective criterion, instead of undermining its validity. The Summa Halensis argues:

In the history of sacred Scripture, the singular fact is introduced in order to signify the universal, and it is therefore that there is understanding and science of [this fact]. ${ }^{18}$

Unlike other stories and historical reports which only refer to individual human acts, the stories told in Scripture are universal; they are exemplary for many events and experiences, and they refer to universal acts and the universal conditions of

\footnotetext{
16 SH I, Tr1, Q1, C1 (n. 1), Ad quod arguet sic 2, p. 1: 'Experientia singularium est, ars vero universalium: fit autem ars, cum ex multis experimento intellectis una fit de similibus acceptio.'

17 Aristotle, Metaphysics I.1, 981a6-8, 981a16-17. In the translatio media, which was apparently used here, the passage reads: 'Fit autem ars, cum ex multis experimento intellectis una fit universalis de similibus acceptio. (...) Experientia quidem singularium cognitio est ars vero universalium,' Aristoteles Latinus XXV.2, Metaphysica: Lib. I-X, XII-XIV: translatio anonyma sive 'media', ed. Gudrun Vuillemin-Diem (Leiden: Brill, 1976), pp. 7-8. Other sources for the criteria seem to be Aristotle, Posterior Analytics I.31, 87b28-88a17, and Aristotle, Posterior Analytics I.33, 88b30-89a3.

18 SH I, Tr1, Q1, C1 (n. 1), Ad obiecta 1, p. 3: 'Introducitur ergo in historia sacrae Scripturae factum singulare ad significandum universale, et inde est quod eius est intellectus et scientia.' See Patrizia Preda, 'L'Epistemologia teologica in Alessandro d'Hales,' Rivista di Filosofia Neo-Scolastica 74:1 (1982), pp. 47-67, esp. pp. 48-50; Bychkov, 'The Nature of Theology,' pp. 16-17.
} 
human nature. Therefore, theological content is universal and intelligible and can belong to a science. ${ }^{19}$

Then the author of the Summa pushes back against a clear-cut division between the credible (credibilis) and the knowable (scibilis). ${ }^{20}$ There are things which are first believed and then understood (postea intelliguntur), credible things which can be united or connected with a science (coniunguntur scientiae), and indeed things which are credible, but ordered towards understanding and science (disponunt ad intellectum et scientiam). These things, such as the divine, can very well belong to a science. $^{21}$

All counterarguments are careful not to water down the necessity of knowability, intelligibility, and universality in a science. They only make the point that certain credible things can be knowable and that certain individual stories can be universal and intelligible.

The author discusses another possible argument against the idea that theology is a science. The argument quotes a passage from Augustine from the context of an exploration of the differences between wisdom and science. Here Augustine explains, 'science' refers to human things, but a science still needs to have a strong connection to faith, it needs to bring about faith, and protect it. ${ }^{22}$ Interestingly, the argument in the Summa twists this thought and makes it into an argument against theology as a science, by claiming that the science of theology can do nothing but bring about faith (non generat nisi fidem). Therefore, it is not a science in the strict sense (non est vero nomine scientia). ${ }^{23}$

The author of this section of the Summa replies by clarifying that theology does indeed generate faith, but by doing so, it brings about intellectual cognition (primo

19 The Summa Halensis distinguishes between four different meanings of universal: aside from the customary sense (i.e. in praedicando), a singular thing can be universal by being an example for many things (in exemplando), by signifying many things (in significando), or by being a cause for many things (in causando). Scripture contains universal statements according to all four meanings; SH I, Tr1, Q1, C1 (n. 1), Ad obiecta 1 and 2, pp. 2-3. See Preda, 'L'Epistemologia teologica,' pp. 55-56; Elisabeth Gössmann, Metaphysik und Heilsgeschichte: Eine theologische Untersuchung der Summa Halensis (Alexander von Hales) (Munich: Max Hueber, 1964), pp. 16-19.

20 SH I, Tr1, Q1, C1 (n. 1), Ad obiecta 3, p. 3: 'Est “credibile” quod nunquam coniungitur scientiae, sicut sunt gesta historica; quaedam vero quae coniunguntur scientiae (...). Non repugnat ergo doctrinam Theologiae esse credibilium et esse scientiam.' See Augustine, De diversis quaestionibus octoginta tribus I.48: De credibilibus, PL 40:31.

21 SH I, Tr1, Q1, C1 (n. 1), Ad obiecta 3, p. 3. See Preda, 'L'Epistemologia teologica,' p. 56; Bychkov, 'The Nature of Theology,' pp. 17-18; Gössmann, 'Metaphysik und Heilsgeschichte,' pp. 19-20. On the resulting necessary multiformity of the science of theology, see SH I, Tr1, Q1, C4, Ar1 (n. 4), Solutio, Ad obiecta 1 and 2, p. 8; SH I, Tr1, Q1, C4, Ar3 (n. 6), esp. Quod autem sit multiformis c, f, and Solutio, pp. 10 -11; SH I, Tr1, Q1, C4, Ar4 (n. 7), I, Solutio, p. 12.

22 Augustine, De Trinitate 14.1.3 (PL 42:1037); English translation in Augustine, On the Trinity, Books 8-15, ed. Gareth B. Matthews, trans. Stephen McKenna (Cambridge: Cambridge University Press, 2002), p. 138.

23 SH I, Tr1, Q1, C1 (n. 1), Ad quod arguet sic 4, p. 2. 
generat fidem, et postea [...] generat intellectum). In the other sciences, intellectual knowledge produces belief, or the assent to certain doctrines, whereas in theology faith produces intellectual knowledge. ${ }^{24}$ Theological faith inspires to assent to the first true thing, or the first truth itself. ${ }^{25}$

This argument is quite noteworthy. The expected reaction to such a one-sided interpretation of a quote would be to rectify the intention of the author, and to point out that Augustine certainly did not think that the fact that a science leads to faith somehow disqualified it from being a science. Quite to the contrary, Augustine uses the orientation towards faith as a positive criterion to distinguish true science in a Christian spirit, through which we reach wisdom, from the vanity and curiosity of other types of human knowledge.

Instead, the Summist opts for a different solution. He further explains what it means for theology to generate faith - but it is not this fact that makes theology a science. The Summa Halensis emphasizes that theology does lead to intellectual knowledge, to an acceptance of the truth. The implicit criterion is, again, that theology is not only connected to faith, but also to the intellect. It is this property which secures its status as a science. ${ }^{26}$

Thus, I think, this passage shows clearly how different the approach of the Summa Halensis is from Augustine's theory of science, and how Aristotelian the conception is. Even though Augustine's words on faith, belief, and knowledge are repeatedly quoted, the author of this section of the Summa works hard not to compromise the essential tie between the term 'science' and the idea of a rational endeavour, dealing with universal intelligibles and leading to certain intellectual knowledge. ${ }^{27}$ He fiercely defends theology against all claims that due to its particular nature it might not count as a science in the strict sense. The strategy is not to adapt the concept of science to fit theology, but to explain how, why, and in what sense theology fulfils the criteria of a science.

\section{What Type of Science is Theology?}

Having defended the scientific status of theology, the author of the Summa Halensis needs to account for the special status of theology among the sciences. It seems clear that its methodology, its sources and origin, and its potential achievements set it

24 This is an example of the voluntaristic tendencies present in the Summa Halensis; see Schumacher, Early Franciscan Theology, pp. 89-96.

25 SH I, Tr1, Q1, C1 (n. 1), Ad obiecta 4, pp. 3-4; see Preda, 'L’Epistemologia teologica,' p. 56. 26 The quotation is repeated later in a context which better fits Augustine's intention; see $S H$ I, Tr1, Q1, C4, Ar1 (n. 4), Solutio, p. 8. There, it supports the fact that the method of acquiring knowledge is different in theology than in the other sciences, and that theology is concerned with the things which lead to salvation.

27 See also SH I, Tr1, Q1, C4, Ar1 (n. 4), Solutio and Ad obiecta 2, p. 8. 
apart from other sciences. The Summist clarifies that theology is not simply like any one among the other sciences (una scientiarum, connumerabilis inter alias). ${ }^{28}$

He explains that, although the peculiarities of theology do not prevent it from being a science in the full sense, theology still proceeds in different ways than the other sciences, and its method (modus) is scientific in a different way than that of sciences which proceed according to the understanding of truth by the human intellect (secundum comprehensionem veritatis per humanam rationem). As mentioned, theology inspires to assent to truths, but it also leads the affective part of the soul towards piety or shapes our affection according to piety (informare affectum secundum pietatem). ${ }^{29}$

When discussing whether the knowledge which is achieved through the theological science is more or less certain than the knowledge achieved in the other sciences, the author answers: neither. He adduces several arguments which defend the claim that theology provides less certainty, as well as arguments for the opposite claim that theology provides a more certain knowledge than the other sciences, since its type of knowledge (modus sciendi) is provided by inspiration and through the testimony of the Holy Spirit. ${ }^{30}$ But the magisterial response to the question defends a balanced position and seems to reject both the claim that theology is less clear, and that theology is more clear than the other sciences. Its certainty is simply of a different kind. Theology is more certain when it comes to the certainty of experience (certitudo experientiae), the certainty according to the affective soul (certitudo secundum affectum), and the certainty concerning the spiritual human soul (certitudo quoad animum spiritualem). It is less certain than the other sciences, however, when it comes to the certainty of the intellect (certitudo secundum intellectum) and of speculation (certitudo speculationis), and regarding the animal part of humans (certitudo quoad animum animalem). ${ }^{31}$

The author stresses these methodological differences because he wants to avoid any impression that all sciences are theology in some sense, or that there could be a conflation between theology and metaphysics. ${ }^{32}$ Instead, theology is a distinct science.

In order to clarify the relation between theology and the other sciences and its role among them, the author introduces two different distinctions between different

28 SH I, Tr1, Q1, C2 (n. 2), Solutio, p. 5.

29 SH I, Tr1, Q1, C4, Ar1 (n. 4), Solutio and Ad obiecta 2, p. 8. See also SH I, Tr1, Q1, C2 (n. 2), Ad obiecta 1-4, p. 5; SH I, Tr1, Q1, C2 (n. 2), Contra f, p. 5.

30 SH I, Tr1, Q1, C4, Ar2 (n. 5), Contra, p. 9; English translation in Boehner, 'The System of Metaphysics,' p. 375. See also SH I, Tr1, Q1, C2 (n. 2), Contra a and b, p. 4.

31 SH I, Tr1, Q1, C4, Ar2 (n. 5), Respondeo, p. 9; English translation in Boehner, 'The System of Metaphysics,' p. 375. See also SH I, Tr1, Q2, M3, C5 (n. 24), Respondeo, p. 36; see Boehner, 'The System of Metaphysics,' pp. 374-75; Preda, 'L’Epistemologia teologica,' pp. 58-59; Bychkov, 'The Nature of Theology,' pp. $20-21$.

32 SH I, Tr1, Q1, C4, Ar1 (n. 4), Ad obiecta 1 and 3, pp. 8-9; SH I, Tr1, Q1, C4, Ar2 (n. 5), Ad obiecta 3 and 4, pp. 9-10. 
types of science, and then ultimately combines both to form a novel system of the sciences.

The first distinction is a bipartition among all sciences. There are 1. sciences of causes (scientia causae) and 2. sciences of caused things, or effects (scientia causati/ causatorum). The first type refers to a science which is concerned with the first uncaused cause or causes. Its object is described as the 'cause of causes' (causa causarum). The second class treats things which are either themselves the causes of further effects, or effects only, without causing anything. ${ }^{33}$

The first type of science exists for its own sake, or is conducted in its own right, with no further aim external to the science itself. This is not true for the second class, however, which is dependent upon a higher cause and refers back (referuntur) to it. ${ }^{34}$

This passage tells us that, according to the Summa Halensis, the nature of the things which a science studies has consequences for the nature and status of the science itself. When an object of investigation is ontologically dependent upon something else, this means the knowledge we can have about this object, and the discipline responsible for providing this knowledge, are also dependent upon the science responsible for the object's cause.

The author of the question then identifies the first type of science as theology. It is the science of the cause of causes, i.e. a science about God. It serves no further or higher purpose than to pursue the knowledge proper to it. All of the other sciences depend upon theology. It transcends (transcendit) them, presumably because it deals with the first cause which is the cause of everything the other sciences are concerned with. ${ }^{35}$ In a further terminological clarification, the text states:

The name of 'science' is applied to the science of caused things, but the name of 'wisdom' to the science of the cause of causes. ${ }^{36}$

This science is properly named 'wisdom' (sapientia), while the name 'science' is, in a certain sense, more appropriate for the second class of sciences, i.e. the sciences of caused things.

The text has stated time and again (and in fact, this is the very claim the question itself defends) that theology is indeed a science. So I do not take this passage to mean that theology is not a science at all. The text introduces an internal distinction between two different types of sciences, namely science which can be referred to as wisdom (i.e. the science of the cause of causes), and science in a narrower sense,

33 SH I, Tr1, Q1, C1 (n. 1), Solutio, p. 2. For this tripartition of the members of a chain of causes see Aristotle, Metaphysics II.2, 994a11-19.

34 SH I, Tr1, Q1, C1 (n. 1), Solutio, p. 2.

35 SH I, Tr1, Q1, C1 (n. 1), Solutio, p. 2.

36 SH I, Tr1, Q1, C1 (n. 1), Solutio, p. 2: 'Nomen ergo scientiae appropriatur scientiae causatorum, nomen vero sapientiae scientiae causae causarum.' 
which is not wisdom. This is simply a different way of phrasing the aforementioned distinction between science of cause and science of effect. ${ }^{37}$

'Wisdom' (sophia) is the term which Aristotle famously uses in his Metaphysics to name the science which he introduces and describes there. ${ }^{38}$ In the Arabic tradition as well, the term 'wisdom' (hikma) becomes prominent. Avicenna introduces it as one of the synonyms for 'metaphysics', in Arabic literally 'the divine science' (al- ilm alilāhī), and uses it extensively. ${ }^{39}$ Augustine, however, makes a distinction between science and wisdom. ${ }^{40}$ Therefore, in the later Latin tradition, the relation between philosophical and theological wisdom and between wisdom and faith becomes a hotly contested topic. ${ }^{41}$

The Summa Halensis positions itself towards these questions and provides its own explanation of what wisdom is. In the eyes of the authors of the Summa, the science which is wisdom has to meet the following criteria: 1 . It is a science concerned not only with causes but with the highest uncaused cause. 2. It contains its own end in itself; it is not conducted for the sake of something external. 3. This means that it is superior to all other sciences which are dependent on this particular science.

The author explicitly adduces these points as explanations for why theology can be described as wisdom, and he makes the source of this set of criteria clear:

Therefore, the Philosopher himself says that first philosophy, which is for its own sake and about the cause of causes, needs to be called wisdom. For a similar reason, theology, which transcends all other sciences, needs to be called wisdom. ${ }^{42}$

37 In this, I disagree with Chenu who takes science and wisdom to be disjuncts, and claims that since theology is wisdom, it is not a science. See Marie-Dominique Chenu, Die Theologie als Wissenschaft im 13. Jahrhundert, trans. Michael Lauble (Ostfildern: Matthias-Grünewald-Verlag, 2008), pp. 75-76, 151-52; Martin Grabmann, Die theologische Erkenntnis- und Einleitungslehre des hl. Thomas von Aquin auf Grund seiner Schrift 'In Boethium de Trinitate' im Zusammenhang der Scholastik des 13. und beginnenden 14. Jahrhunderts (Fribourg: Paulusverlag, 1948), p. 190.

38 Aristotle, Metaphysics I.1, 981b28; I.2, 982a20.

39 Avicenna, Metaphysics I.1, Avicenna, The Metaphysics of The Healing, ed. and trans. Michael E. Marmura (Provo, UT: Brigham Young University Press, 2005), p. 3.5-15, §9-10/ Avicenna, Grundlagen der Metaphysik: Eine Auswahl aus den Büchern I-V der Metaphysik, ed. and trans. Jens Ole Schmitt (Freiburg: Herder, 2016), pp. 38-41/ Avicenna, Liber de philosophia prima sive scientia divina, I-IV, ed. Simone van Riet (Louvain: Peeters, 1977), vol. 1, pp. 3-4; Avicenna, Metaphysics I.2, ed. Marmura, pp. 11.17-12.4, §18/ ed. Schmitt, pp. 66-67/ ed. Van Riet, vol. 1, p. 16.

40 Augustine, De Trinitate 12.14.22 (PL 42:1009-10); English translation in Augustine, On the Trinity, trans. McKenna, p. 98.

41 Andreas Speer, 'Sapientia nostra: Zum Verhältnis von philosophischer und theologischer Weisheit in den Pariser Debatten am Ende des 13. Jahrhunderts,' in Nach der Verurteilung von 1277, ed. Jan A. Aertsen, Kent Emery Jr. et al. (Berlin: De Gruyter, 2001), pp. 248-75; Gregory F. LaNave, 'God, Creation, and the Possibility of Philosophical Wisdom: The Perspectives of Bonaventure and Aquinas,' Theological Studies 69 (2008), pp. 812-33.

42 SH I, Tr1, Q1, C1 (n. 1), Solutio, p. 2: 'Unde et ipse Philosophus dicit quod Philosophia Prima, quae est sui gratia et de causa causarum, debet dici sapientia. Simili ratione doctrina theologica, quae 
The source for the Summa's conception of wisdom is named as 'the Philosopher'. While in the later tradition this epithet is used almost exclusively to refer to Aristotle, the Summa Halensis uses it more ambiguously. There are cases in which philosophus refers to thinkers other than Aristotle. Sometimes theories which cannot be found in Aristotle but instead only in Avicenna are ascribed to this 'Philosopher'. ${ }^{43}$ The quotation at hand seems to be one of the instances in which it is not clear whether the author thinks of Aristotle or Avicenna, or simply does not distinguish between them.

Aristotle introduces all of the characteristics in his description of the science of metaphysics: it exists and is pursued solely for its own sake, ${ }^{44}$ it is the science which is responsible for studying the first causes, the immaterial and divine substances, and God, and metaphysics, or wisdom, is the first, highest, and divine science. ${ }^{45}$

Aristotle himself, however, does not use the expression 'cause of causes' to refer to what is treated in metaphysics, i.e. the highest cause. Instead, the Summa Halensis seems to have adopted this expression from Avicenna who uses it several times in the Metaphysics of his Šifä'. The most prominent passage, and the most likely source for the author of this section of the Summa, occurs in the very beginning of the Metaphysics, where Avicenna discusses the subject-matter of metaphysics. In the Latin translation of this work, to which the authors of the Summa Halensis had access, it reads:

You have also heard that the divine science is the one in which the first causes of natural and mathematical existence and what relates to them are investigated; and [so also is] the Cause of Causes and Principle of Principles - namely, God, exalted be His greatness. ${ }^{46}$

The context here is the very same in which the Summist uses the expression. The divine science (Avicenna means metaphysics) is about the cause of causes, which is identified with God. In a later passage Avicenna claims that the ultimate final cause can be described as the cause of all other causes, ${ }^{47}$ and states: the science

\footnotetext{
transcendit omnes alias scientias, debet dici sapientia.' See Boehner, 'The System of Metaphysics,' pp. 377-78, Preda, 'L’Epistemologia teologica,' p. 53.

43 Bertolacci, 'Reading Aristotle with Avicenna,' pp. 146-52; Hasse, Avicenna's De anima in the Latin West, p. 53; Aertsen, Medieval Philosophy as Transcendental Thought, p. 141.

44 Aristotle, Metaphysics I.2, 982b24-28.

45 Aristotle, Metaphysics I.2, 982a25-b10, 983a5-11; VI.1, 1026a19-23; XII.6, 1071b3-5.

46 Avicenna, Metaphysics I.1, ed. Marmura, p. 2.15-17, § 7/ ed. Schmitt, pp. 38-39/ ed. Van Riet, vol. 1, pp. 2-3: 'Iam etiam audisti quod scientia divina est in qua quaerunt de primis causis naturalis esse et doctrinalis esse et de eo quod pendet ex his, et de causa causarum et de principio principiorum, quod est Deus excelsus.' (The English translation is Marmura's from the Arabic, but is also adequate for the Latin which is very literal here.)
}

47 Avicenna, Metaphysics VI.5, ed. Marmura, p. 229.5-6, § 30 and p. 229.11-13, §31/ ed. Van Riet, vol. 2, pp. 338-39. 
which is concerned with this cause of causes is the most noble of sciences, namely wisdom. ${ }^{48}$

Avicenna is not mentioned as an authority in this context in the Summa Halensis, however. Instead of explicitly naming either Aristotle or Avicenna, the author refers to 'the Philosopher'.

While both Aristotle and Avicenna apply the term 'wisdom' to metaphysics, and describe metaphysics as existing for its own sake and being about the highest cause, the Summa stresses the shared properties of metaphysics and theology and it adopts the philosophical reasoning for ascribing to both the status of 'wisdom'. Both of these sciences fulfil the criteria established by Aristotle and Avicenna.

But the text also introduces a second distinction between different types of sciences which it then uses to establish a difference between metaphysics and theology:

It has to be noted that there is a science which perfects cognition according to truth, and there is also a science which moves affection towards goodness. The first is like cognition according to sight, and therefore it needs to be called absolute science; the second [is] like cognition according to taste, and therefore it needs to be called wisdom from the taste of affection. ${ }^{49}$

There is (a) science which perfects the faculty of cognition, i.e., the intellect, according to truth, which probably means, by fulfilling the intellectual striving for truth. And there is (b) science which moves the faculty of affection towards goodness. The first type of science (a) is compared to the sense of sight, the second (b) to the sense of taste..$^{50}$

The reference to the senses might be metaphorical, but I think the passage also works as an analogy: both senses are directed towards the same sensible things and

48 The Latin translation reads: 'Si autem de unaquaque istarum causarum esset scientia per se, utique nobilior inter eas esset scientia de finali; et ipsa esset sapientia.' Avicenna, Metaphysics VI.5, ed. Marmura, p. 235.17, §54/ ed. Van Riet, vol. 2, p. 348.

49 SH I, Tr1, Q1, C1 (n. 1), Solutio, p. 2: 'Notandum quod est scientia perficiens cognitionem secundum veritatem; est etiam scientia movens affectionem ad bonitatem. Prima est ut cognitio secundum visum, et ideo debet dici scientia absoluta; secunda, ut cognitio secundum gustum, et ideo debet dici sapientia a sapore affectionis.'

50 See Schumacher, Early Franciscan Theology, pp. 97-99; Boehner, 'The System of Metaphysics,' pp. 371-74, 377-78; Preda, 'L'Epistemologia teologica,' pp. 51-52. The idea that wisdom is connected to taste (sapor or gustus) can also be found in other texts from the period, for instance in William of Auxerre, see Inos Biffi, 'Teologi dell'università di Parigi nella prima metà del XIII secolo,' in La nuova razionalità: XIII secolo, eds. Inos Biffi and Costante Marabelli, Figure del pensiero medievale, vol. 4 (Rome: Città Nuova; Milan: Jaca Book, 2008), pp. 237-98, esp. p. 294; Boyd Taylor Coolman, Knowing God by Experience: The Spiritual Senses in the Theology of William of Auxerre (Washington, DC: The Catholic University of America Press, 2004), pp. 211-15. Another source could be an anonymous text from the 1220s which states that the intellect, or science, reaches the first truth through the sense of sight, and wisdom through the sense of taste; see Daniel A. Callus, 'The Powers of the Soul: An Early Unpublished Text,' Recherches de théologie ancienne et médiévale 19 (1952), pp. 131-70, esp. pp. 162-63. 
both can grasp the same objects. Likewise, truth and goodness are both transcendentals, and the highest goodness and the highest truth are ontologically identical both are only found in God. So both types of science, as well, are directed towards the same object or goal. But the two senses of sight and taste strive for their object in different respects. Sight is directed towards the property of visibility and senses things insofar as they are visible, while taste senses them insofar as they are 'tastable'. Similarly, the intellect is directed towards the highest being as the highest truth, while the affectionate parts of the human soul are directed towards God as the highest good; and the same applies to the sciences associated with them.

This is precisely the difference between theology and metaphysics: Theology moves the human soul towards the good through fear and love. Metaphysics is also about the highest cause, but it perfects the human intellect by using the means of scientific argument and syllogistic conclusion (secundum viam artis et ratiocinationis).

When discussing the argument that theology and metaphysics could be one and the same science since both are divine, ${ }^{51}$ the Summist rejects the idea that both sciences are about God in the same sense and thus indistinguishable. Indeed, theology is characterized as the divine science. A science is divine when and if it is from God, about God, and leads to God (a Deo et de Deo et ductiva ad Deum). And this is only true for theology.52 Theology treats God with regard to the Trinity and the sacrament of humans' reparation (secundum mysterium Trinitatis vel secundum sacramentum humanae reparationis). Neither metaphysics (Prima Philosophia) nor any other science achieves this, so it is a unique feature of theology. Only theology leads to God 'through the principle of fear and love through faith in the justice and mercy of God' (per principium timoris et amoris ex fide misericordiae et iustitiae Dei). ${ }^{53}$

The author rejects a direct comparison between these two sciences and their respective ways of acquiring knowledge. Confronted with the claim that what is known in the manner of taste could be known more certainly than what is known in the manner of sight (certius est quod scitur per modum gustus quam quod per modum visus), he responds, as mentioned before: these are simply two different ways of ac-

51 SH I, Tr1, Q1, C2 (n. 2), Ad quod obicitur sic 2, p. 4.

52 SH I, Tr1, Q1, C2 (n. 2), Ad obiecta 1-4, p. 5; English translation in Boehner, 'The System of Metaphysics,' p. 376. See also SH I, Tr1, Q1, C4, Ar2 (n. 5), Ad obiecta 2, p. 9. See Schumacher, Early Franciscan Theology, pp. 96-97; Boyd Taylor Coolman, 'On the Subject-Matter of Theology in the Summa Halensis and St Thomas Aquinas,' The Thomist: A Speculative Quarterly Review 79:3 (2015), pp. 439-66, esp. pp. 440 - 41; Boyd Taylor Coolman, 'Hugh of St Victor's Influence on the Halensian Definition of Theology,' Franciscan Studies 70 (2012), pp. 367-84, esp. pp. 377-78; Preda, 'L'Epistemologia teologica,' p. 66; Bychkov, 'The Nature of Theology,' pp. 18-19.

53 SH I, Tr1, Q1, C2 (n. 2), Ad obiecta 1-4, p. 5; English translation in Boehner, 'The System of Metaphysics,' p. 376. 
quiring certain knowledge. Theology is more certain in one regard, but less certain in the other..$^{54}$

I think it is important to remember that even though the author of the passage describes the perfection of cognition as something that is proper to metaphysics (and possibly the other theoretical sciences), and uses this criterion to distinguish it (or them) from theology, theology is still an intellectual endeavour. As the author has emphasized again and again, we must think of theology as a habit of the intellect. It is a science and it is about universal intelligibles. Hence, we can assume, the difference between metaphysics and theology lies more in the fact that metaphysics does not move the affective soul towards the good, than in the fact that theology does not perfect the intellect. As a science it would have to do so, at least partly.

Finally, the Summa Halensis combines the two different systems of distinction it had introduced and presents its final system of the different types of sciences:

Theology is wisdom as wisdom; but first philosophy, which is cognition of the first causes which are goodness, wisdom, and power, is wisdom, but as science; the other sciences, however, which consider the attributes of [their] subject-matter through their causes, are sciences as sciences. ${ }^{55}$

Most sciences (2) treat caused things. They are sciences in the most typical sense, sciences as sciences. ${ }^{56}$ Metaphysics is cognition of the first uncaused causes (1), but it does not move the soul towards the good, but rather perfects the human intellect through cognition of the truth (1a). It is wisdom, but wisdom as a science. Theology, finally, is also concerned with God, the first uncaused cause (1), and - in addition to perfecting the intellect, we have to assume - it moves the affective soul towards the good through love and fear (1b). Therefore, it is wisdom in the highest sense, wisdom as wisdom. ${ }^{57}$

So theology is more deserving of the label of wisdom: Theology is wisdom properly and primarily (proprie et principaliter), while metaphysics can only be called wis-

54 SH I, Tr1, Q1, C4, Ar2 (n. 5), Contra and Respondeo, p. 9; English translation in Boehner, 'The System of Metaphysics,' p. 375.

55 SH I, Tr1, Q1, C1 (n. 1), Solutio, p. 2: 'Doctrina Theologiae est sapientia ut sapientia; Philosophia vero Prima, quae est cognitio primarum causarum, quae sunt bonitas, sapientia et potentia, est sapientia, sed ut scientia; ceterae vero scientiae, quae considerant passiones de subiecto per suas causas, sunt scientiae ut scientiae.'

56 It is not quite clear how the second distinction between sciences perfecting the intellect (a) and sciences leading the affective soul towards goodness (b) relates to the sciences dealing with caused things (2). The author of the Summa Halensis explicitly states that the property of leading to God through love and fear is specific to theology only. He seems to think that some other sciences (such as ethics) also have an effect upon the affective part of the soul. See SH I, Tr1, Q1, C2 (n. 2), Ad obiecta 1-4, p. 5. Then, a difference could be drawn between (2a) sciences which only perfect the intellect, and (2b) sciences which lead towards the good.

57 SH I, Tr1, Q1, C1 (n. 1), Solutio, p. 2. 
dom in a less proper way (minus proprie). ${ }^{58}$ The Summa Halensis on the one hand adopts the Aristotelian definition of wisdom and applies it to the science of theology. But it also modifies it and denies that metaphysics - the science for which the term in this sense was coined by Aristotle - carries the full and primary meaning of wisdom. Instead, the descriptor in its purest form is claimed for theology because it is not only about the cause of causes but also influences the affective soul.

\section{The Subject-Matter of Theology}

Having clarified the status of theology and its place among the other sciences, the author turns to what is commonly referred to as the subject-matter of the science. The Arabic readers of Aristotle, most notably Avicenna and Averroes, explicitly discussed the subject-matter (Arabic: mawdī̄', in the Latin translation of both of their works rendered as subiectum) of metaphysics and the other sciences, and after the Latin translation of their works it became a staple topic in the discussion of sciences in the Latin Middle Ages. The Summa Halensis interestingly does not use the term subiectum, but instead uses materia, or simply asks what the science of theology is about, or the science of what it is. This terminology is rather unusual and shows that the Summa was written before the standard vocabulary for discussing these matters was developed (which, I would say, happened with Albert the Great's Commentary on the Metaphysics in the 1260s). ${ }^{59}$

In order to answer the question of the subject-matter of theology, the Summa Halensis introduces a distinction which, I will argue, was actually adopted from Avicenna. The Summist states that a science can be about something in two different ways. To express this difference, two different Latin phrases (both of which can be translated as 'the subject-matter about which [the science is]') are used: 1. materia de qua and 2. materia circa quam.

58 SH I, Tr1, Q1, C1 (n. 1), Solutio, p. 2. See Boehner, 'The System of Metaphysics,' p. 376; Preda, 'L'Epistemologia teologica,' pp. 53-54.

59 The Memoriale quaestionum in Metaphysicam Aristotelis, sometimes ascribed to Richard Rufus of Cornwall and written in the 1230s, interestingly uses the term subiectum in this context, see Richard Rufus of Cornwall, Memoriale in Metaphysicam Aristotelis, eds. Rega Wood and Neil Lewis (2013), available at https://rrp.stanford.edu/MMet.shtml, preface. See Rega Wood, 'Richard Rufus of Cornwall,' in A Companion to Philosophy in the Middle Ages, eds. Jorge J. E. Gracia and Timothy N. Noone (Malden, MA: Blackwell, 2002), pp. 579-87, esp. pp. 581-82; Rega Wood, 'The Earliest Known Surviving Western Medieval Metaphysics Commentary,' Medieval Philosophy and Theology 7 (1998), pp. 39-49. 
The subject-matter is taken in two ways in the sciences: that 'of (de) which' and that 'about (circa) which' [a science is]. (...) Therefore, according to this, theology is a science of (de) the divine substance which can be known through Christ in the work of reparation. ${ }^{60}$

The author further explains the first of these and applies it to the case of theology: Materia de qua can itself be used in three different respects: ${ }^{61} 1 \mathrm{a}$. according to the criterion of work (secundum rationem operationis), and in this sense the works of reparation of the human genus (opera reparationis humani generis) are the subject-matter of theology; ${ }^{62} 1 \mathrm{~b}$. according to the criterion of virtue (secundum rationem virtutis), and in this respect the subject-matter is Christ who, according to Scripture, ${ }^{63}$ is the virtue and wisdom of God; and 1c. according to the criterion of essence (secundum rationem essentiae), which here refers to the divine essence, or God.

All three of these are in different respects the de qua-subject-matter of theology. The Summist explains their relation: theology is about the divine essence which can be known through Christ in the work of reparation (scientia de substantia divina cognoscenda per Christum in opere reparationis). ${ }^{64} \mathrm{God}$, the cause of all things, becomes known to us through the work of reparation, the virtue of Christ. ${ }^{65}$

The materia circa quam of theology, on the other hand, is introduced in the discussion of Peter Lombard's claim that theology is about things and signs (res et signa). These, according to the Summa Halensis, are not the materia de qua of theology, but rather its materia circa quam. ${ }^{66}$

60 SH I, Tr1, Q1, C3 (n. 3), Solutio, p. 6: 'Materia dupliciter accipitur in scientiis: "de qua" et "circa quam". (...) Unde secundum hoc Theologia est scientia de substantia divina cognoscenda per Christum in opere reparationis.' See Boehner, 'The System of Metaphysics,' p. 371; Aertsen, Medieval Philosophy as Transcendental Thought, p. 136; Coolman, 'Hugh of St Victor's Influence on the Halensian Definition,' pp. 381-83; Coolman, 'On the Subject-Matter of Theology in the Summa Halensis,' pp. 441-42, 444-47; Preda, 'L'Epistemologia teologica,' p. 57.

61 In this, the Summa Halensis follows Pseudo-Dionysius the Areopagite, De Coelesti Hierarchia, eds. Günter Heil and Adolf Ritter, 2nd ed. (Berlin: De Gruyter, 2012), XI.2, pp. 41-42.

62 SH I, Tr1, Q1, C3 (n. 3), Ad obiecta 1, p. 6. In a discussion of Hugh of St Victor's claim that theology is about the works of reparation, but using Aristotle's idea that every science treats one genus of beings and all the species which fall under this genus, the author explains that these works of reparation are also the genus of things which the science of theology investigates. See Hugh of St Victor, De Sacramentis Christianae fidei, prologue, c. 2 (PL 176:183-84); On the Sacraments of the Christian Faith (De Sacramentis), ed. and trans. Roy J. Deferrari (Eugene, OR: Wipf and Stock, 2007), pp. 3-4; Aristotle, Posterior Analytics, I.10, 76b11-76b22; Aristotle, Metaphysics III.2, 997a18-22; IV.2, 1003b19-36.

631 Cor. 1:24.

64 SH I, Tr1, Q1, C3 (n. 3), Solutio, p. 6. Coolman, 'On the Subject-Matter of Theology in the Summa Halensis,' pp. 447-49, states that for the Summa Halensis the works of reparation are not themselves included in the de qua-subject-matter of theology, but are only instrumentally relevant. On the basis of this passage, which makes clear that the divine essence, Christ, and the works of reparation are all in different respects materia de qua of theology, I disagree with this reading.

65 SH I, Tr1, Q1, C3 (n. 3), Ad obiecta 2, p. 6.

66 SH I, Tr1, Q1, C3 (n. 3), Ad obiecta 3, pp. 6-7. 
Confronted with the problem of how one single science can possibly deal with all things and all signs, ${ }^{67}$ the author answers that both signs and things are considered in one respect, and insofar as they are related to one thing (sit relatio considerationis ad unum), namely the human conformation to God and the human reformation through Christ. ${ }^{68}$ This is highly reminiscent of Aristotle who argues that the science of metaphysics treats all beings. But since these are connected through their relation to one common principle, it can still be one unified science. ${ }^{69}$ Likewise, the author of the Summa Halensis is careful to make sure that the unity of theology as a science can be retained in spite of the science's enormous scope.

But the source of this distinction between two different ways in which a science can be about the things it considers, is not Aristotle but Avicenna. Avicenna famously introduces a distinction between the proper, actual subject-matter of a science (mawḍ̄ $/$ subiectum) and that which is sought in a science (mațlūb/ quaesitum). The subject-matter itself has to fulfil certain systematic requirements; it is like a genus whose species and accidents the science investigates. Everything in the science is studied with respect to this. In the case of metaphysics, this means (according to the Latin translation):

Therefore, the first subject-matter of this science is being insofar as it is being, and the [things] which it inquires are those that accompany being insofar as it is being unconditionally. ${ }^{70}$

The thing which is sought, on the other hand, is what the science primarily aims to investigate. The study of this is the perfection of the science and its noblest part, and to learn about it and to prove its existence is indeed the intention of the science:

Knowledge of God is the aim of this science. Many things are named after that which is the noblest in them, or after their noblest part, or after the part which is like the aim in them. Therefore, this science will be like [the science] whose perfection and whose more noble part and whose first intention is knowledge of that which is separate from nature in every way. ${ }^{71}$

67 SH I, Tr1, Q1, C3 (n. 3), Contra 4, p. 6.

68 SH I, Tr1, Q1, C3 (n. 3), ad 4, p. 7: 'Ad illud vero quod obicitur de unitate scientiae quae non est rerum et signorum: respondendum quod hoc est ubi est separata ratio considerationis rei et signorum. Hic vero non separatur consideratio, cum sit relatio considerationis ad unum, quod est reformatio hominis ad similitudinem Dei seu conformatio hominis ad Deum per opus reparationis a Christo.' 69 Aristotle, Metaphysics IV.2, 1003a33-b16.

70 Avicenna, Metaphysics I.2. ed. Marmura p. 10.2-3, §12/ ed. Schmitt, p. 60/ ed. Van Riet, vol. 1, p. 13: 'Ideo primum subiectum huius scientiae est ens, inquantum est ens; et ea quae inquirit sunt consequentia ens, inquantum est ens, sine condicione.' See also Avicenna, Metaphysics I.2, ed. Marmura, pp. 7.1-12.17, §1-20/ ed. Schmitt, pp. 52-69/ ed. Van Riet, vol. 1, pp. 9-17.

71 Avicenna, Metaphysics I.3, ed. Marmura, p. 18.4-7, § 16/ ed. Schmitt, pp. 86-87/ ed. Van Riet, vol. 1, p. 26: 'Cognitio enim Dei finis est huius scientiae; multae enim res appellantur ab eo quod est in eis dignius, vel a parte digniore, vel a parte quae est eis quasi finis. Erit igitur haec scientia quasi cuius perfectio et cuius pars aliqua nobilior et cuius prima intentio est cognitio eius quod separatum est a natura omnimodo.' See also Avicenna, Metaphysics I.1, ed. Marmura, pp. 3.13-4.14, 
This distinction regarding the inner structure of a science is parallel to the distinction introduced in the Summa Halensis. Like Avicenna's subject-matter, the materia circa quam in the Summa seems to be everything about which a science makes investigations, everything it treats or considers. The materia de qua, on the other hand, is something more specific, just like that which a science seeks according to Avicenna. It is described in the Summa as the aim and the intention of the science, and seems to consist of the things that a science is primarily about, the things which only this science properly and uniquely investigates.

That Avicenna's metaphysical considerations are the source for the equivalent distinction in the Summa Halensis is supported by the fact that the Summist invokes the case of metaphysics in order to further illuminate his take on the subject-matter of theology. He explains what the respective subject-matters, i.e. the materia de qua and the materia circa quam, of metaphysics are:

For instance it can be said about first philosophy that its circa quam-subject-matter is everything - and therefore it is said that it is about all things, because it is about being according to all of its differences, according to the different divisions of being, namely being in potency, being in act, one being and many, substantial and accidental being, and the like - but the subject-matter about which (de qua) [its] intention [is], is being which is one in its act, which is the first substance, on which everything depends. ${ }^{72}$

In line with his earlier claim that metaphysics is about God, but in a different way than theology, the author states that the materia de qua of metaphysics is the first substance which is the cause of everything, or the being which is one through its act. He also adds that it is the intention (intentio) of metaphysics to explore this subject-matter. ${ }^{73}$ This idea that the materia de qua represents the intention of the science also applies to theology. ${ }^{74}$

The materia circa quam of metaphysics is everything. Metaphysics is about (circa) being according to all its specific differences and different distinctions,

$\S 10-12 /$ ed. Schmitt, pp. 40-45/ ed. Van Riet, vol. 1, pp. 4-5. Also Avicenna, Metaphysics I.3, ed. Marmura, pp. 14.19-15.2, §6/ ed. Schmitt, pp. 76-77/ ed. Van Riet, vol. 1, p. 21.

72 SH I, Tr1, Q1, C3 (n. 3), Ad obiecta 3, p. 7: 'Quemadmodum est dicere de Philosophia Prima quod materia circa quam est sunt omnia - unde et dicitur esse de omnibus, quia est circa ens secundum omnem sui differentiam, secundum differentes divisiones entis, scilicet ens potentia, ens actu, ens unum et multa, ens substantia et accidens, et huiusmodi - materia vero de qua intentio, est ens actu unum, quod est substantia prima, a qua omnia dependent.' See Aertsen, Medieval Philosophy as Transcendental Thought, p. 136; Coolman, 'On the Subject-Matter of Theology in the Summa Halensis,' pp. 442-43; Coolman, 'Hugh of St Victor's Influence on the Halensian Definition,' p. 379.

73 SH I, Tr1, Q1, C3 (n. 3), Ad obiecta 3, pp. 6-7.

74 See SH I, Tr1, Q1, C3 (n. 3), Ad obiecta 7, p. 7, where the Summa Halensis states that the end and the subject-matter of a science are not mutually exclusive. For some sciences, their subject-matter is the same as their end or final cause (idem habet pro materia et fine). In the case of theology, Christ is indeed both the subject-matter, in the sense explained above, and the end of the science. 
such as potential and actual being, one and many, substantial and accidental being, etc.

Coming back to theology, the Summa concludes that, since the materia circa quam of theology are things and signs, theology in a way treats everything, just like metaphysics. But unlike metaphysics, it does not treat all beings according to all possible different respects and in every way (secundum omnem modum sive secundum omnium rationem). The Summa Halensis stresses that theology studies all things in one respect, i.e. in the one way that is proper to the science (secundum unum proprium modum et rationem). This respect is the human reparation through the incarnation of Christ which ultimately leads to enjoyment of the Trinity. ${ }^{75}$

We can see that, regarding the content of these two concepts (materia circa quam/ subject-matter, and materia de qua/ that which is sought) when applied to metaphysics, the Summa Halensis again follows Avicenna. Aristotle of course mentions that metaphysics is concerned with the divine separate substance and the first being ${ }^{76}$ and he also explains how metaphysics is the science concerned with investigating being insofar as it is being. ${ }^{77}$ But Aristotle famously does not provide a clear and satisfactory explanation of how these two different descriptions of the science fit together.

Avicenna develops his theory of the distinction between what is sought and what is a subject-matter in the Metaphysics of his Šifä' precisely as a solution to this problem: metaphysics treats all of these disparate objects but treats them in a different manner. The science is in one sense about the first substance because that is what is sought, and it is in another sense about every being, and the species and differences of being, since these are its proper subject-matter.

The innovation of the Summa's approach lies in the application of the Avicennian theory to the science of theology. Similarly to Avicenna who has to explain the disparate character of metaphysics, the Summa Halensis is faced with diverging an-

75 SH I, Tr1, Q1, C3 (n. 3), Ad obiecta 5, p. 7: 'Etsi agat de omnibus, non tamen secundum rationes differentes omnium, sed secundum unam rationem, quae est ut homo reparatus per sacramenta incarnationis (...) perveniat ad fruenda, quae sunt Pater et Filius et Spiritus Sanctus, incommutabile bonum.' See Coolman, 'On the Subject-Matter of Theology in the Summa Halensis,' pp. 446-47, 449. In his interpretation of this passage, Coolman claims that the text makes the following analogy: Metaphysics is primarily about the first cause and studies it and all beings through the ratio of being, while theology is about (de) the Trinity and studies or knows it through the works of reparation. I do not think that this interpretation holds, however. It is true that, according to the authors of the Summa Halensis, the ratio with respect to which metaphysics studies everything, coincides in a sense with the extension of its circa quam-subject-matter (i.e. being is considered insofar as it is being). But that is not the case for theology: The theological analogue to being as the materia circa quam of metaphysics are all things and signs, and the analogue to being as the ratio is the human reformation and conformation to God. The things and signs are not considered as things and signs, and thus metaphysics and theology differ from each other even though both treat all beings.

76 Aristotle, Metaphysics I.2, 982a25-b10, 983a5-11; VI.1, 1026a19-23; XII.6, 1071b3-5.

77 Aristotle, Metaphysics IV.1, 1003a20-26, 1003b12-36. 
swers to the question of what theology is about (the essence of God, the Trinity, the sacraments, the works of reparation, all things and signs, etc.). It uses Avicenna's conception of metaphysics in order to explain in what sense theology is concerned with all of these concepts respectively, and thus solves the problem of the subjectmatter of theology.

While it is extremely likely that the Summist has adopted this theory from Avicenna, he clearly uses a different terminology. This type of reception seems fairly typical of the Summa's approach to sources like Avicenna. ${ }^{78}$ The Summist here takes over a theory or a piece of doctrine from a pagan or Muslim source, but he does not use the original author's own terminology but cloaks it, or rather, assimilates it into his own vocabulary, which is closer to the traditional Christian sources.

In this case, the terminology used in the Summa Halensis is taken from Peter Lombard. At the very beginning of book I of his Sentences, when Peter Lombard introduces Augustine's distinction between signs and things which can be treated in sciences, he uses the expression 'circa res vel signa'. ${ }^{79}$ Augustine himself states in his De doctrina Christiana that every science is either about signs or about things (Omnis doctrina vel rerum est vel signorum), but he does not use the preposition circa. ${ }^{80}$ The Summa names both of these authorities and partially quotes the passage from the Sentences twice in the chapter in question. ${ }^{81}$ Replying to the argument that the signs and things should be the subject-matter of the science of theology, the author of the Summa clarifies that theology is indeed - exactly as claimed in the Sentences - about (circa) these.

So the Summa Halensis adopts the terminology from the Sentences, where circa is by no means a technical expression, and forges the phrase into one half of a systematic distinction between two different ways in which a science relates to the things it studies - a distinction taken over from Avicenna.

\section{Conclusion}

As I showed in the first step of my argument, the author of this section of the Summa Halensis defends theology against all claims that due to its particular nature it might not count as a science in the strict sense. Upholding an Aristotelian understanding of

78 Bertolacci, 'Reading Aristotle with Avicenna.'

79 Peter Lombard, Sententiae in IV libris distinctae, ed. Ignatius C. Brady, 2 vols (Grottaferrata: Editiones Collegii S. Bonaventurae, 1971-81), vol. 1, pt. 1, bk. 1, d. 1, c. 1, p. 55. The whole passage reads: 'Veteris ac novae Legis continentiam diligenti indagine etiam atque etiam considerantibus nobis, praevia Dei gratia innotuit sacrae paginae tractatum circa res vel signa praecipue versari.'

80 Augustine, De doctrina Christiana, bk. 1, c. 2 (PL 34:19), English translation in Augustine, City of God and Christian Doctrine, trans. Philip Schaff (New York: The Christian Literature Publishing Co., 1890), p. 827.

81 SH I, Tr1, Q1, C3 (n. 3), Contra 3, p. 6 and Ad obiecta 3, pp. 6-7. 
the concept of science as a rational endeavour, dealing with universal intelligibles and leading to certain intellectual knowledge, the author of the Summa claims that theology does meet all necessary criteria.

In the second step, I showed how theology is then integrated into a unique and innovative system of sciences: Sciences in general are divided - on the one hand into sciences of causes, meaning sciences of the first uncaused cause, and these are theology and metaphysics, and sciences of secondary causes and effects, and these are all the particular sciences, sciences as sciences. On the other hand, sciences are divided into sciences which perfect the faculty of cognition, i.e. metaphysics and the other theoretical sciences, and sciences which move the affective part of the soul towards goodness, including theology.

The Summa Halensis picks up on Avicenna's expression of describing wisdom as the science of the 'cause of causes', and it uses Aristotle's definition of metaphysics as wisdom, and applies this to theology, even claiming that theology is wisdom in a stronger sense than metaphysics. Even though metaphysics is concerned with God, theology is the singular divine science. Theology is still about everything, in a sense, i.e. about all things and signs, but the Summa Halensis, using Aristotle again, makes sure to still stress the unity of the science which is guaranteed through the fact that everything is studied in the same respect.

In response to the problem of how the different things that theology is about fit together within the inner structure of the science, the author adopts Avicenna's distinction between the proper subject-matter and that which is sought within a science, but uses his own terminology, taken from Peter Lombard.

The Summa Halensis attempts, on the one hand, to harmonize the competing claims of what theology is about by arguing that it is about several different concepts in different ways. By creating a structure of different categories among the things a science treats, the Summist gives this thesis a systematic underpinning. On the other hand, he harmonizes the criteria of science in general, and of the highest science of the first cause in particular, with the Christian requirements of a divine science. The author tries to balance both by carefully putting forth certain properties which theology shares with all sciences (or at least with metaphysics), and others which are unique to theology and set it apart.

As we have seen, this theory of theology as a science in the Summa Halensis is interwoven with the theories and arguments of Aristotle and Avicenna. The author takes their doctrines regarding scientific methodology, the properties of wisdom, and the inner structure of a science extremely seriously. However, he also merges them with other sources such as Augustine, and applies them to new systematic problems the original authors were not concerned with, such as the difference between metaphysics and theology.

Through the use of these sources the Summa Halensis can thus offer an innovative answer to the newly arisen systematic problem of theology as a science. 
